(Житомирський національний агроекологічний університет) tetyana.lesegmail.com ORCID: 0000-0003-3190-454X

\title{
ОСОБЛИВОСТІ ЗМІСТУ НАВЧАННЯ АНГЛІЙСЬКОЇ МОВИ ПРОФЕСІЙНОГО СПРЯМУВАННЯ СТУДЕНТІВ СПЕЦІАЛЬНОСТІ "МЕНЕДЖМЕНТ ЗОВНІШНЬОЕКОНОМІЧНОЇ ДІЯЛЬНОСТІ"
}

\author{
У статті обгрунтовано необхідність оновлення змісту курсу "Англійська мова" для студентів \\ спеціальності "Менеджмент зовнішньоекономічної діяльності", проаналізовано иляхи інтеграції \\ завдань із розвитку професійної фахової та комунікативної компетенції майбутніх менеджерів, \\ досліджено шляхи відбору навчального матеріалу для вивчення англійської мови відповідно до принщипів \\ автентичності, контекстуальної обумовленості, інтенсивного використання фонових знань та \\ інтегрованого навчання.
}

\section{Ключові слова: зміст навчання, навчальний текст, фахова компетенція менеджера, комунікативна} компетениія менеджера.

Вступ. Підготовка кваліфікованих спеціалістів у сфері менеджменту сьогодні передбачає високий рівень знання іноземної мови та готовність до міжнародного співробітництва. На факультеті економіки та менеджменту Житомирського національного агроекологічного університету проводиться активна робота 3 обміну аспірантами та викладачами з різними країнами світу, зокрема 3 Литвою, Польщею, Німеччиною, Францією, Японією. Оскільки зміст навчання іноземної мови визначається освітньопрофесійними програмами підготовки та змінюється відповідно до рівня розвитку науки, культури, виробництва та суспільства [1], до методики викладання іноземних мов студентам негуманітарних спеціальностей висуваються відповідні вимоги із врахування фахової специфіки при вивченні мови.

Проблеми формування іншомовної комунікативної компетенції досліджувалися вітчизняними та зарубіжними вченими: Г. А. Гринюк, Р. О. Гришковою, Х. I. А. Мухаммада, Н. М. Прудніковою, Л. О. Сікорською, А. В. Щеколдіною, С. Донни, П. Еммерсоном. Вітчизняними вченими-методистами створено серію методик для немовних ВН3, зокрема для ВНЗ економічного профілю (Е. Мірошніченко, I. Онісина), для менеджерів (Ю. Друзь, Л. Логутіна) тощо. Проте у вітчизняній науці недостатньо уваги приділено практичному аспекту розробки змісту навчання іноземної мови студентів з огляду на фахову спеціалізацію.

Тому в своїй практичній діяльності викладачам доводиться працювати в умовах відсутності підручників з іноземної мови з урахуванням фахової спеціалізації, і перед викладачами стоїть завдання $з$ самостійної розробки навчальних програм та підготовки матеріалу для кожної спеціалізації. Метою дослідження $є$ розробка рекомендацій щодо вибору дидактичного навчального матеріалу для викладання курсу англійської мови для студентів спеціальності "Менеджмент організацій".

Завдання статті:

дослідити особливості змісту навчання іноземної мови з огляду на специфіку професійної діяльності майбутніх фахівців;

- проаналізувати види та джерела навчального матеріалу;

- обгрунтувати принципи визначення змісту навчального матеріалу курсу "Англійська мова" для студентів спеціальності "Менеджмент організацій".

Зміст навчання - це науково обгрунтований методичний та дидактичний навчальний матеріал, засвоєння якого забезпечує здобуття освіти і кваліфікації згідно з освітньо-кваліфікаційним рівнем. Зміст курсу іноземної мови визначається метою формування у студентів іншомовної професійно спрямованої комунікативної компетенції - умінь і навичок здійснювати спілкування в усній і письмовій формі у межах професійної сфери і тематики, визначених програмою для відповідного фаху, дотримуючись традицій і норм, усталених у країні, мова якої вивчається [2: 197]. Навчання іноземних мов у немовному ВНЗ передбачає оволодіння студентами навичками й уміннями іншомовної комунікації в суто професійних цілях.

Виклад основного матеріалу. Логічним розвитком загальноприйнятого комунікативного підходу до навчання іноземної мови студентів немовних спеціальностей стало "навчання через зміст" (D. Brinton, T. Dudley-Evans, M. St. John, M. Wesche), яке передбачає визначення змісту навчання англійської мови 3 урахуванням специфічних потреб студентів, за критерієм відповідності майбутній професійнокомунікативній діяльності.

Продіус О. І. та Продіус Ю. І. окреслюють такі вимоги до професійної компетенції майбутніх менеджерів: 
- здатність мислити новим чином, генерувати інноваційні бізнес-ідеї, перетворюючи їх у нові технології з метою отримання доходу;

вміння здійснювати пошук нових ринкових можливостей для бізнесу;

- вдатність оперативно оцінювати перспективність нових ринкових можливостей для бізнесу, економічні та соціальні умови здійснення підприємницької діяльності;

- здатність розробляти бізнес-плани створення та розвитку нових організацій, напрямків діяльності, продуктів;

- $\quad$ здатність до прийняття рішень, готовність взяти на себе відповідальність за наслідки рішень;

- $\quad$ розуміння суті проблеми і вміння знаходити новаторські рішення проблеми в стандартних та нестандартних ситуаціях;

- вміння налагоджувати зв'язки, домовлятися, здійснювати комунікацію з різними партнерами, укладати ефективні угоди;

- вміння контролювати використання ресурсів, забезпечувати оптимальне розподілення ресурсів між операціями та проектами;

- здатність ризикувати, уміння управляти ризиками;

- $\quad$ здатність до особистісного та професійного розвитку;

- $\quad$ здатність до критичної оцінки особистих переваг та недоліків [3: 72].

За умови обгрунтованого підходу до вибору навчального матеріалу, методів, засобів та форм навчання, вивчення іноземної мови студентами спеціальності "Менеджмент зовнішньоекономічної діяльності" сприяє набуттю студентами професійної компетенції та досвіду практичної реалізації професійних знань, умінь та навичок.

Розглянемо приклад інтеграції завдань із розвитку професійної фахової та комунікативної компетенції за на базі тематичного розділу "Project management".

3 огляду на вимоги до фахової підготовки, спеціаліст, менеджер повинен вміти управляти різноманітними проектами.

Управління проектами - це комплекс взаємопов'язаних заходів, орієнтованих на досягнення чітко визначених цілей впродовж певного періоду часу та в рамках встановленого бюджету. У своїй професійній діяльності менеджери постійно працюють над проектами - розробка нових продуктів, вихід на нові ринки, реорганізація підприємства, відкриття дочірніх підприємств, укладання нових угод, впровадження нового програмного забезпечення тощо.

Студенти повинні, в першу чергу, мати знання про проектну діяльність в обсязі, достатньому для іiі реалізації, а саме: управління часом, управління людьми, вирішення конфліктів, надання зворотного зв'язку, ведення переговорів, складання презентацій, розподіл обов'язків, делегування обов'язків тощо.

Необхідність здійснення комунікації англійською мовою виникає у випадку наявності англомовних членів команди, необхідності взаємодії 3 партнерами-носіями англійської мови, необхідності опрацювання джерел інформації іноземною мовою тощо. У такому випадку менеджер повинен здійснювати усну та письмову комунікацію.

Особливості усної комунікації, яка здійснюється в усній та письмовій формі, визначаються професійною спрямованістю. Діалог відбувається в наступних ситуаціях: щоденне спілкування як в персональній, так і в особистій площині; індивідуальні та групові зустрічі з командою; переговори тощо. Монолог має місце під час презентації проекту, звітів, публічних виступів. Також у процесі проектної діяльності виникає необхідність в письмовому спілкуванні, яке має такі форми: електронні комунікації, звіти, матеріали для презентації, юридичні документи тощо.

Відповідним чином визначаються також ситуації, де виникає необхідність у застосуванні навичок аудіювання та читання.

Наведений приклад ілюструє важливість розвитку іншомовної комунікативної компетенції, яка $є$ якісною характеристикою особистості фахівця та охоплює сукупність науково-теоретичних знань, практичних умінь і навичок у сфері здійснення професійної комунікації, досвід здійснення професійної взаємодії, стійку мотивацію професійного спілкування.

Навчальний матеріал є основою змісту навчання англійської мови за професійним спрямуванням. Як зазначає Г. В. Барабанова, у немовному ВНЗ універсальною дидактичною одиницею професійноорієнтованого навчання $\epsilon$ автентичний текст, який надає матеріал для організації навчального спілкування [4: 15].

Ми погоджуємося із запропонованими принципами визначення змісту навчання та відбору матеріалу: автентичність; прагматичність; професійна адекватність (з урахуванням терміносистеми галузі студента); врахування очікувань студентів [5]. 
Тексти для розробки курсу англійської мови для студентів спеціалізації "Менеджмент" ми поділяємо на інформаційні та автентичні. Під автентичними текстами ми розуміємо зразки іншомовної професійної діяльності у відповідній сфері, тобто фактичні документи, записи, зразки тощо.

Джерела пошуку англомовних текстів для читання опрацювання:

- інформаційні інтернет-джерела;

- тренінги;

- книжки за спеціалізацією;

- новини;

-

- блоги;

- публікації соціальних мереж;

- справжні зразки англомовних текстів: резюме, договори, публічні звіти компаній, презентації продукції зарубіжних компаній, бізнес-плани тощо.

Тексти для аудіювання:

- презентації продукції компаній;

- покасти;

- $\quad$ новини (радіо) тощо.

Зміст навчального матеріалу повинен не лише забезпечувати набуття студентами знань, умінь та навичок професійного спілкування англійською мовою, але й підвищувати професійну мотивацію студентів, сприяти їхньому особистісному розвитку.

Відео для опрацювання:

- $\quad$ записи на YouTube;

- блоги;

- $\quad$ художні фільми;

- випуски телевізійних новин тощо.

Для розділу "Project Management" ми пропонуємо скористатися серією відео, доступ до яких безкоштовно надається на сайті https:/www.apm.org.uk/golden-rules.

Навчання професійно-орієнтованого читання, згідно з Г. Барабановою, включає такі етапи:

- передтекстове введення мовного матеріалу для формування тематичного термінологічного мінімуму;

- самостійне читання автентичного навчального тексту;

- $\quad$ навчальне аудиторне читання тексту, що супроводжується серією текстових вправ для розуміння змісту прочитаного;

- робота над функціонально-композиційною структурою тексту з метою анотування тексту [4: 67].

Ми користуємося загальноприйнятою структурою роботи з текстом: передтекстовий, текстовий та післятекстовий етап.

На передтекстовому етапі включаються вправи на співвіднесення термінів і картинок, термінів та визначень, визначення вірних та невірних тверджень тощо. Метою цієї стадії є створення автентичного середовища спілкування та забезпечення студентів фоновими знаннями, що, у свою чергу, веде до природної реакції студентів (автентична методика) в процесі навчання іноземної мови [6: 8]. На передтекстовому етапі доцільно скористатися інфографікою з соціальних джерел на відповідну тему для підвищення мотивації студентів та ознайомлення їх із проблематикою тексту.

Для студентів спеціалізації "Менеджмент" доцільно розробляти завдання 3 читання автентичних текстів у формі проекту. На передтекстовому етапі студенти отримують або самостійно формулюють завдання із професійного життя менеджера, і в процесі опрацювання тексту знаходять шляхи вирішення цього завдання. Наприклад, під час опрацювання розділу "Project Management" базовим текстом $\epsilon$ "Delegation of project duties". Студенти отримують завдання, на кшталт таких:

- You are managing the project on moving your entire office to another facility.

- $\quad$ You are head of the project on developing a new snack.

- You are in charge of a team-building seminar.

- $\quad$ You will manage hiring a new team for our IT department.

На перед текстовому етапі студенти повинні спланувати виконання своїх проектів, поділитися своїми планами з групою, передбачити поради стосовно делегування обов'язків, про які йтиметься в тексті.

На текстовому етапі навчальний текст опрацьовується за допомогою вправ на засвоєння мовних одиниць, нової інформації та культурних особливостей за наявності. Студенти можуть відзначати аспекти, які їм вдалося передбачити на передтекстовому етапі, вставляти слова в пропуски у реченнях тексту, відновлювати послідовність абзаців або речень у тексті тощо.

На післятекстовому етапі студенти обговорюють прочитаний текст англійською мовою на основі питань та завдань, запропонованих викладачем. У ході обговорення з'ясовується, наскільки те, що прочитали, відрізняється від припущень, зроблених на передтекстовому етапі, як співвідноситься 
отримана інформація з тим, що було раніше відомо, які висновки можна зробити 3 того, про що довідалися, тощо. Завдання після текстового етапу передбачають розвиток студентами навичок монологічного та діалогічного мовлення, а також письма.

Для вищенаведеного прикладу тексту, який опрацьовується у форматі міні-проекту, доцільним буде влаштувати рольову гру: студенти можуть робити презентацію проекту для групи, розподіляючи обов'язки між студентами-"членами групи" (роль), або обговорити сильні сторони один одного для успішного розподілу обов'язків, поділитися досвідом командної роботи, передбачити основні проблеми, які можуть виникнути в ході виконання проекту. 3 огляду на можливий недостатній рівень володіння англійською мовою, студенти можуть висловлювати свою точку зору на базі міні-діалогів, мовленнєвих зразків, запропонованих викладачем.

Дегтярьова Ю. В. пропонує етапи та принципи переробки автентичних текстів у навчальний текст:

1) Додавання інформації 3 метою забезпечення зв'язку тексту 3 попереднім та наступним навчальним матеріалом;

2) Вилучення частин оригінального тексту, які є менш важливими з точки зору відібраної тематики спілкування;

3) З'єднання відібраних частин оригінальних текстів по-новому, таким чином, щоб уникнути порушення логіки висловлювання [6: 11].

Висновки. Зміст навчання іноземної мови професійного спрямування студентів спеціальності "Менеджмент організацій" потребує оновлення, з огляду на актуальні вимоги до професійного розвитку майбутніх менеджерів. У статті проаналізовано шляхи відбору навчального матеріалу курсу "Англійська мова" з урахуванням таких вимог та принципів автентичності, контекстуальної обумовленості, інтенсивного використання фонових знань та інтегрованого навчання. Результати дослідження є основою для оновлення змісту навчальної програми та дидактичних матеріалів курсу "Англійська мова" для студентів спеціалізації "Менеджмент".

\section{СПИСОК ВИКОРИСТАНИХ ДЖЕРЕЛ ТА ЛІТЕРАТУРИ}

1. Закон України "Про вищу освіту" від 1 липня 2014 року // Голос України. - 06.08.2014. - № 148. - Режим доступу : http://zakon2.rada.gov.ua/laws/show/1556-18.

2. Коваль Л. М. Формування у студентів немовних вищих навчальних закладів англомовної професійно орієнтованої мовної компетенції / Л. М. Коваль // Науковий вісник НЛТУ України. - 2010. - Вип. 20.4. C. $318-321$

3. Продіус О. І. Компетентнісний підхід у підготовці майбутніх менеджерів в сфері зовнішньоекономічної діяльності. Шляхи реалізації кредитно-модульної системи організації навчального процесу і тестових форм контролю знань студентів [текст] : матеріали наук.-метод. семінару / О. І. Продіус, Ю.І. Продіус ; [під ред. Гогунського В. Д.]. - Вип. 7 : Методологічні основи дистанційного навчання. - О. : Наука і техніка, 2013. $120 \mathrm{c}$.

4. Барабанова Г. В. Методика навчання професійно-орієнтованого читання в немовно-му ВН3/ Г. В. Барабанова. - К. : ІНКОС, 2005. - 101 с.

5. Крат О. І. Компоненти системи навчання іноземної мови професійного спрямування через зміст професійної діяльності / О. І. Крат // Вісник Дніпропетровського університету імені Альфреда Нобеля. Серія "Педагогіка і психологія". Педагогічні науки. - 2011. - № 2 (2).

6. Дегтярьова Ю. В. Методика навчання студентів вищих немовних навчальних закладів читання англійською мовою для ділового спілкування : автореф. дис... канд. пед. наук / Ю. В. Дегтярьова ; Київ. нац. лінгв. ун-т. K., 2006. $-22 \mathrm{c}$.

\section{REFERENCES (TRANSLATED \& TRANSLITERATED)}

1. Zakon Ukrainy "Pro Vyschu Osvitu" [The Law of Ukraine on Higher Education] as of July 1 $1^{\text {st }} 2014 / /$ Holos Ukrainy [Holos Ukrainy]. - 06.08.2014. - № 148. - Rezhym dostupu : http://zakon2.rada.gov.ua/laws/show/155618.

2. Koval L. M. Formuvannia u studentiv nemovnykh vyshchykh navchal'nykh zakladiv anglomovnoi profesiyno oriientovanoi movnoi kompetentsii [Teaching a Foreign Language to Students of Non-Linguistic Specialities to Form the Competence of Professional Communication in English] / L. M. Koval // Naukovyi visnyk NLTU Ukrainy [Scientific Bulletin of UNFU]. - 2010. - Vyp. 20.4. - S. 318-321.

3. Prodius O. I. Kompetentnisnyi pidhid u pidhotovtsi maybutnikh menedzheriv v sferi zovnishnioekonomichnoi diial'nosti. Shliakhy realizatsii kredytno-modul'noi systemy organizatsii navchal'nogo protsesu i testovykh form kontroliu znan' studentiv [text] : [materialy nauk.-metod. seminaru] [Competence-Based Approach to Educating Future Managers in the Field of Inport and Export. Ways of Implementing the Credit-Module System of Educational Process and Control Test Forms of Students' Knowledge] / O. I. Prodius, Yu. I. Prodius ; pid red. Hohuns'kogo V. D. - Vyp. 7 : Metodolohichni osnovy dystantsiinoho navchannia. - O. : Nauka i tekhnika, 2013. - $120 \mathrm{~s}$.

4. Barabanova H. V. Metodyka navchannia profesiino-oriientovanoho chytannia v nemovnomu VNZ [The Methods of Teaching Professionally-Oriented Reading at Non-Linguistic Universities] / H. V. Barabanova. - K. : INKOS, 2005. $-101 \mathrm{~s}$.

5. Krat O. I. Komponenty systemy navchannia inozemnoi movy profesiinoho spriamuvannia cherez zmist profesiinoi diial'nosti [Elements of the System of Teaching Foreign Languages for Professional Purposes through the 
Professional Subject Matter] / O. I. Krat // Visnyk Dnipropetrovs'koho universytetu imeni Al'freda Nobelia. Seriia "Pedahohika i psykhologiia". Pedahohichni nauky [Bulletin of Alfred Nobel University. Series "Pedagogy and Psychology". Pedagogy]. - 2011. - № 2 (2).

6. Diehtiariova Yu. V. Metodyka navchannia studentiv vyshchykh nemovnykh navchal"nykh zakladiv chytannia anhliys'koiu movoiu dlia dilovoho spilkuvannia [Methods of Teaching Reading for Business Purposes to Students of Non-Linguistic Universities] : avtoref. dys... kand. ped. nauk / Yu. V. Diehtiariova ; Kyiv. nats. linhv. un-t. - K., 2006. $-22 \mathrm{~s}$.

Лесь Т. В. Особенности содержсания обучения иностранному языку профессиональной направленности студентов специальности "Менеджсмен организаций".

В статье обоснована необходимость обновления содержания курса "Английский язык" для студентов специильности "Менеджмент организаций", проанализировань пути интеграции заданий по развитию профессиональной спецฺиализированной и коммуникативной компетенции будущих менеджеров, исследованы пути отбора ученого материала для изучения английского языка в соответствии с принципами аутентичности, контекстуальной обусловленности, интенсивного применения фоновых знаний и интегрированного обучения.

Ключевые слова: содержание обучения, учебный текст, профессиональная компетениця менеджера внешнеэкономической деятельности, коммуникативная компетенция менеджера.

\section{Les T. V. Special Aspects of Teaching English for Professional Purposes to Students Specializing in Managing International Business Operations.}

The research deals with the problem of updating the content of teaching English to students of non-linguistic specializations, in particular to future managers of international business operations. The topicality of the research is accounted for by the existing discrepancy between theoretical university training and current requirements to the qualifications and expertise of job candidates in the aforementioned field. The course of the English language provides numerous opportunities for building and developing knowledge and skills of students pertaining to their professional specialization due to the possibilities of including textual, audio-and video materials related to the specific job-based subject matters. The objective of the article is to provide recommendations on selecting and compiling learning materials for teaching English to future managers of international business operations. The material of the research highlights the requirements to professional communication skills of the students and explores the correlation between the said requirements and the possibilities provided by thoroughly selected subject matter of learning texts based on a case study of a teaching unit of "Project management". The results of the research provide guidelines on selecting learning materials, the sources thereof and stages of their studying in view of the learning tasks that correspond to actual future job responsibilities of the students. The conclusions made provide grounds for updating the content of teaching English, selecting learning materials and methods for actualization of background knowledge and principles of integrated learning into the course of English for professional purposes designed for students specializing in managing international business operations.

Key words: content of teaching English, learning text, professional qualifications of managers of international business operations, communicative competence of managers. 